\title{
Perceptual Differences in Service Quality
}

\author{
Thevaranjan Dinesh ${ }^{1}$, Kugathasan Pushpakaran ${ }^{2}$ \\ ${ }^{I}$ (Department of Management, Faculty of Commerce and Management, Eastern University, Sri Lanka) \\ ${ }^{2}$ (Department of Economics, Faculty of Commerce and Management, Eastern University, Sri Lanka)
}

\begin{abstract}
The major aim of the research paper is to find out whether there are any differences between the employee's perception and customer's perception towards service quality in commercial banks. Primary data has been collected from the bank employees and customers in Manmunai North and Kattankudy divisional secretariat areas in Batticaloa District. Stratified random sampling was used to obtain 225 responses from employees of banks and quota sampling was used to obtain 225 responses from customers of banking services. The collected data were used to test the differences using t-test and ANOVA analysis. The results imply that there are differences in the service quality between the employees' and customers' perception. Employees perceive the service quality at higher level compared to the perception of customers. Several insights for this difference were discussed.
\end{abstract}

Keywords: customer perception, employee perception, service quality

\section{Introduction}

As the importance and size of the service sector of the global economy grows, the study of services is becoming increasingly important. Services are distributed regionally, nationally, and globally and are increasingly becoming a larger portion of many organizations' revenue streams. With the aim of sustaining long term relationships with their customers, many businesses have changed their strategic focus to emphasize customer retention (Peng and Wang, 2006). Preserving their long term customer relationships requires that these businesses both measure and appropriately adjust the quality of their customer service. Service organizations are continuously endeavouring their quality of service, as it is of paramount importance to them (Berry and Parasuraman, 1997). In Global scenario, the improvement in the service quality is becoming a competitive weapon to avail comparative advantages in the market.

Whereas academics and managers consider customer perceptions of quality as crucially important, employee perceptions of service quality do not appear to have been sufficiently studied. In fact during service co-production, employee perceptions of most important quality attributes affect their interactions with customers during the service encounter (Luk and Layton, 2002). Employee assessments of quality attributes may be quite different from that of customers. Indeed, they may refer to the same quality attributes as customers to assess service quality, but evaluate or rank them in a different manner, or they may not share the same quality attributes with customers at all. They can underestimate or overestimate how the service is delivered or how quality is evaluated for instance (Seiders, 2009). In both cases, employee perceptions of quality will have an impact on their behaviour during the encounter and thus on customer perceived service quality.

For service managers, it is fundamental to know whether, or to what extent, employees have the same perceptions of quality attributes as customers. The more employees share the same perceptions as customers, the more they will be able to put themselves in their place and deliver quality by adapting their role to the specifics of the customer and the service encounter (Rohini and Mahadevappa, 2006).

\section{Research Problem}

Pratyush and Berg (2003) indicated that there is a gap between the employee's perception and customer's perception towards service quality in commercial banks. Customer contact employees or service employees are, in effect, intermediate customers of various support services and intermediate service quality problems result in problems at the consumer level (Zeithaml, Parasuraman, and Berry, 1990). Rust and Oliver (2005) pointed out that service quality has three distinct components: customer's criteria of service quality, company or the commercial bank employees' perception of service quality, and the relationship among these components. There is a big question that is whether employees' perception of service quality differs from customers' perception of service quality.

This scenario in turn questions about the differences between employees' perception and customers' perception towards service quality. This study addresses this as an issue, thus questioning in general:

"Whether there are any differences between employees' perception and customers' perception of ervice quality?" 


\section{Research Objective}

Based on the problem statement, this research was carried out to discover whether there are any differences between employees' and customers' perceptions towards service quality

\section{Literature review}

Various efforts have been declared to improve services and processes from the perspective of customers in the private and public sectors. Most of them have focused on the satisfaction of external customer requirements. Most researches have revealed that these programs have failed to live up to initial expectations. Consequently, consultants and experts have called for a broader-based organizational focus to include the perspective of employees and their interrelationships with both managers and customers (Gowan et al, 2001).

Customers as an important factor have got more attention in customer service research (Atkins et al., 2002; Bowden, 2000). Customer centricity has been around for a long time. Drucker (1954) and Levitt (1960) have suggested that customers are the main reason for any business to exist and that customer needs are the most important thing to focus in order to be successful. However, effective customer centric service business orientation relies primarily on the employee's competences and skills to deliver service quality. The touch points of many service business activities can be the key factors that contribute to the overall service satisfaction. Employee-centric service organisations are more likely to achieve superior performance, because ultimately the production and delivery of service quality is dependent on the employees' attitudes and skills (Vella et al., 2009)

Pratyush and Berg (2003) did a study on "Managing Information Technology for Service Quality in Electric Utility Industry". That model examined the relationship between information system and service quality from the perception of employees. They justified that, since the relationship is only visible to the employees, they investigated the relationship between information system (IS) and service quality from employee perspective. However, they also mentioned that as the customers are evaluating the service, service quality should be measured from customer perspective. Parasuraman, Zeithaml and Berry (1988) define service quality as a difference between customer expectation of service and customers' perceptions of the actual service. Kasper (1999) defines service quality as the degree to which the service offered can satisfy the expectations of the user. According to these definitions, customers are the sole judges of service quality.

Zeithaml, Parasuraman, and Berry (1990) explained that employees of the service organizations may cause several problems in the service offered to customers. Their arguments were that, employees perceive the service quality of their organization in a high level because they are the ultimate service providers. Rationally, no one will underestimate quality of service he/she provides. Even though employees perceive the quality of service they provide in a high level, due to the problems faced by customers, customers may perceive the quality of service they receive, in a low level compared with employees' perspective. Further, Vannirajan and Manimaran (2009), after doing a study about the impact of management information system (MIS) on service quality from employees' perspective, recommended that future studies should evaluate the service quality from both the employees' and customers' perspectives as there may be differences between the perception measures of two parties.

\subsection{Sampling}

\section{Research Method}

This study aimed to consider 450 sample respondents, who were the employees of commercial banks in Batticaloa district (Manmunai North and Kattankudy divisional secretariat areas) and customers of the particular banks in Batticaloa district (225 sample respondents from employees' side and 225 sample respondents from customers' side). The above said two divisional secretariat areas were selected for this study as they were identified as areas with people who engage in banking transactions frequently.

Total number of information system (IS) related employees in the selected commercial banks are 256. Stratified random sampling method was applied to select the samples of employees as the population framework was clearly identified. Stratified random sampling procedure can be adopted when the whole population is known. To conduct this sampling procedure, the researcher prepared the sampling frame and from this list, the samples were chosen which means equal chance of selection is provided for the samples. Questionnaire was dispatched to 256 employees. 245 were received, however only 238 ones were valid. 13 questionnaires were randomly excluded from the research based on the sample size.

On the other hand, the population framework for the customers of the selected banks was not available as the banks did not provide this information due to confidentiality issues. Therefore, quota sampling method was applied to select the customers of the selected banks. Quota sampling is useful when a sampling frame is not available and it is used to select the subjects or units from each segment based on a specified proportion (http://en.wikipedia.org/wiki/Quota_sampling, seen on 18th July 2015). Proportion measures were derived according to the valid employee questionnaires. For example, if the valid employee questionnaire from Seylan 
bank - Batticaloa branch is $5 \%$ of the total valid employee questionnaires, then the proportion to select the customer samples from Seylan bank - Batticaloa branch is $5 \%$.

\subsection{Data Collection}

For the purposes of this research, two sets of questionnaire were used to gather the necessary information. One set was for the employees and the other was for the customers. In an attempt to make it beneficial for both the researcher and the respondent, the questionnaires were distributed through personal visits to the banks and customers' premises for the purpose of self-administering. Due to the time restrictions, customer questionnaires were also distributed electronically via social networks and 66 questionnaires were collected. The most widely used models in measuring service quality in the banking sector are the SERVQUAL and SERVPERF models (Mesay Sata Shanka, 2012). According to the SERVQUAL model (Parasuraman et al., 1988), service quality can be measured by identifying the gaps between customers' expectations of the service to be rendered and their perceptions of the actual performance of the service. The SERVPERF model was carved out of SERVQUAL by Cronin and Taylor in 1992. SERVPERF measures service quality by using the perceptions of customers. Cronin and Taylor argued that only perception was sufficient for measuring service quality and therefore expectations should not be included as suggested by SERVQUAL (Baumann C, 2007). The SERVPERF scale is found to be superior not only as the efficient scale but also more efficient in reducing the number of items to be measured by 50\% (Hartline and Ferrell, 1996; Babakus and Boller, 1992). In this study, the SERVPERF scale was used to measure service quality in commercial banks in Batticaloa district. Two additional statements were added with the model in order to avoid ambiguities. Many studies have been conducted by adopting the SERVPERF model; some of the most relevant are given in Table 1.

Table 1: Studies conducted by adopting SERVPERF.

\begin{tabular}{|l|l|}
\hline Authors & Country \\
\hline Beerli A (2004) & Spain \\
\hline Wang (2003) & China \\
\hline Lee and Hwan (2005) & Taiwan \\
\hline Zahoor (2011) & Pakistan \\
\hline Mensah (2010) & Ghana \\
\hline Sulieman (2011) & Jordan \\
\hline
\end{tabular}

Source: Mesay Sata Shanka (2012)

In the customer questionnaire, service quality (dependent variable) was measured with the same dimensions and statements which were used in the employee questionnaire in order to maintain the consistency in the service quality variable between two sets of questionnaires.

\subsection{Methods of Data Analysis and Evaluation \\ 5.3.1 Analysis of Variance}

Coolican (1999, p. 389) explains that "Analysis of variance procedures are powerful parametric methods for testing the significance of differences between sample means where more than two conditions are used, or even when several independent variables are involved." ANOVA makes it feasible to appraise the separate or combined influences of several independent variables on the experimental criterion (Mouton and Marais, 1990). In one-way ANOVA, the total variation is partitioned into two components as between groups and within groups. Between groups represents variation of the group means around the overall mean. Within group represents variation of the individual scores around their respective group means. Significant value indicates the significant level of the F-test.

Testing hypothesis of ANOVA analysis

$\mathrm{H}_{0}$ : There are no significant differences among study variables $(\mathrm{p} \geq 0.05)$

$\mathrm{H}_{1}$ : There are significant differences among study variables $(\mathrm{p}<0.05)$

Decision: Accept $\mathrm{H}_{1}$, if $\mathrm{p}<0.05$.

\subsection{2 t-Test}

This test is used to identify the significant difference between the two variables. In this research, among the several t-tests, the independent sample t-test was used. The Independents-samples t- test procedure compares means for two groups of cases.

Testing hypothesis of independent sample t-test

$\mathrm{H}_{0}$ : There are no significant differences between two group means $(\mathrm{p} \geq 0.05)$

$\mathrm{H}_{1}$ : There are significant differences between two group means $(\mathrm{p}<0.05)$

Decision: Accept H1, if $\mathrm{p}<0.05$. 


\subsection{Differences across nature of ownership}

\section{Data Analysis}

The analysis was carried out to check whether there are any differences in service quality between state and private commercial banks. The results of the analysis are presented in Table 2.

Table 2: Independent sample t-test - Nature of ownership

\begin{tabular}{|c|c|c|c|c|c|}
\hline \multirow{2}{*}{ Test Variable } & \multicolumn{2}{|c|}{ Levene's Test for Equality of Variances } & \multicolumn{3}{|c|}{ t-test for Equality of Means } \\
\cline { 2 - 6 } & $\mathbf{F}$ & Sig. & $\mathbf{t}$ & $\mathbf{d f}$ & Sig. (2-tailed) \\
\hline Service quality & 8.904 & 0.003 & -6.025 & 112.342 & 0.000 \\
\hline
\end{tabular}

Levene's test for equality of variances indicates that variances for respondents differ significantly ( $p$ value 0.003 is less than 0.05 ) between state and private banks. Then 'Equal-Variance Not Assumed' assumption was taken and t-test for equality of means was carried out to compare average values between state and private banks. As the p-value for service quality from the t-test for equality of means is less than the significance level 0.05 , it can be concluded that there is sufficient evidence to say at the $5 \%$ level of significance, that "there are significant differences in service quality between state and private commercial banks in Batticaloa district". This finding can be explained clearly with the mean values of each of the study variables as shown in Table 3.

Table 3: Group statistics - Nature of ownership

\begin{tabular}{|c|l|c|c|c|}
\hline Variable & Nature of Ownership & $\mathrm{N}$ & Mean & Standard Deviation \\
\hline \multirow{2}{*}{ Service Quality } & State & 72 & 3.5979 & 0.0610 \\
\cline { 2 - 5 } & Private & 153 & 4.0138 & 0.0323 \\
\hline
\end{tabular}

The above table shows that the mean values of service quality for state banks is less than the mean values of private bank. Therefore, it can be summarized that service quality is perceived in a high level in private banks compared with state banks.

\subsection{Differences across DS Divisions}

The analysis was carried out to check whether there are any differences in service quality perceptions between the customers of Manmunai North DS division and the customers of Kattankudy DS division. The results of the analyses are presented in Table 4.

Table 4: Independent sample t-test- DS divisions

\begin{tabular}{|c|c|c|c|c|c|}
\hline \multirow{2}{*}{ Test Variable } & \multicolumn{2}{|c|}{ Levene's Test for Equality of Variances } & \multicolumn{3}{|c|}{ t-test for Equality of Means } \\
\cline { 2 - 6 } & $\mathrm{F}$ & Sig. & $\mathrm{t}$ & $\mathrm{df}$ & Sig. (2-tailed) \\
\hline Service quality & 2.483 & 0.117 & -0.538 & 223 & 0.591 \\
\hline
\end{tabular}

Levene's test for equality of variances indicates that variances for respondents do not differ significantly (p-value 0.117 is greater than 0.05) between two DS divisions. Then 'Equal-Variance Assumed' assumption was taken and t-test for equality of means was carried out to compare average values between two DS divisions (Manmunai North and Kattankudy). As the $p$-value $(p=0.591)$ for service quality from the t-test for equality of means is more than the significance level 0.05 , it can be concluded that there is sufficient evidence to say at the 5\% level of significance, that "there are no significant differences in service quality between the customers of Manmunai North DS division and the customers of Kattankudy DS division”.

\subsection{Differences between Genders}

The analysis was carried out to check whether there are any differences in service quality between male and female customers of commercial banks. The results of the analyses are presented in Table 5.

Table 5: Independent sample t-test - Gender of customers

\begin{tabular}{|c|c|c|c|c|c|}
\hline \multirow{2}{*}{ Test Variable } & \multicolumn{3}{|c|}{ Levene's Test for Equality of Variances } & \multicolumn{4}{c|}{ t-test for Equality of Means } \\
\cline { 2 - 6 } & $\mathrm{F}$ & Sig. & $\mathrm{t}$ & $\mathrm{df}$ & Sig. (2-tailed) \\
\hline Service Quality & 0.532 & 0.466 & 1.503 & 223.00 & 0.134 \\
\hline
\end{tabular}

Levene's test for equality of variances indicates that variances for genders do not differ significantly ( $p$-values is greater than 0.05) from each other. Then 'Equal-Variance Assumed' assumption was taken and ttest for equality of means was carried out to compare average values between male and female customers of commercial banks. The $\mathrm{p}$-value $(\mathrm{p}=0.134)$ from the $\mathrm{t}$-test for equality of means is more than the significance level 0.05 . Therefore, it can be concluded that there is sufficient evidence to say at the $5 \%$ level of significance, that "there are no significant differences in service quality between male and female customers of commercial banks in Batticaloa district". 


\subsection{Differences across residency area of customers}

The analysis was carried out to check whether there are any differences in service quality perceptions between the customers from rural area and the customers from urban area. The results of the analyses are presented in Table 6.

Table 6: Independent sample t-test- Residency area

\begin{tabular}{|c|c|c|c|c|c|}
\hline \multirow{2}{*}{ Test Variable } & \multicolumn{2}{|c|}{ Levene's Test for Equality of Variances } & \multicolumn{3}{|c|}{ t-test for Equality of Means } \\
\cline { 2 - 6 } & $\mathrm{F}$ & Sig. & $\mathrm{t}$ & $\mathrm{df}$ & Sig. (2-tailed) \\
\hline Service quality & 2.430 & 0.120 & -0.284 & 223 & 0.777 \\
\hline
\end{tabular}

Levene's test for equality of variances indicates that variances for respondents do not differ significantly (p-value 0.120 is greater than 0.05 ) between two residency areas. Then 'Equal-Variance Assumed' assumption was taken and t-test for equality of means was carried out to compare average values between two residency areas (Rural and Urban). As the $\mathrm{p}$-value $(\mathrm{p}=0.777)$ from the $\mathrm{t}$-test for equality of means is more than the significance level 0.05 , it can be concluded that there is sufficient evidence to say at the $5 \%$ level of significance, that "there are no significant differences in service quality between the customers from rural area and the customers from urban area".

\subsection{ANOVA analysis related to differences in service quality}

ANOVA analysis was carried out to check whether there are any differences in service quality across several demographic characteristics of customers of commercial banks. The results of the analyses are presented in Table 7.

Table 7: ANOVA - Demographic characteristics of customers

\begin{tabular}{|l|c|c|}
\hline \multicolumn{1}{|c|}{ Demographic Factor } & F & Sig. \\
\hline Age of Customers & 0.955 & 0.433 \\
\hline Ethnicity of Customers & 0.557 & 0.644 \\
\hline Level of Education of Customers & 0.923 & 0.451 \\
\hline Occupation of Customers & 2.096 & 0.067 \\
\hline Income of Customers & 1.563 & 0.148 \\
\hline Frequency of Using Bank Services & 0.804 & 0.493 \\
\hline Account Type & 2.844 & 0.025 \\
\hline
\end{tabular}

In the table, the $\mathrm{F}$ statistic values for the differences in mean values along with its significance values have been presented. As the p-values for all the demographic factors except 'Account Type' are more than the significance level 0.05 , it can be concluded that there is sufficient evidence to say at the $5 \%$ level of significance, that "there are no significant differences in service quality across the age of customers, ethnicity of customers, level of education of customers, occupation of customers, income of customers and customers' frequency of using bank services with regard to commercial banks in Batticaloa district".

However, as the $p$-value for the factor 'Account Type' $(p=0.025)$ is less than the significance level 0.05 , it can be concluded that there is sufficient evidence to say at the $5 \%$ level of significance, that "there are significant differences in service quality across the account types used by customers of commercial banks in Batticaloa district". To find out the differences in detail, Post-Hoc analysis was carried out. The results of the analysis are presented in Table 8 .

Table 8: Post-Hoc analysis - Types of account or service

\begin{tabular}{|l|l|c|c|}
\hline Type of Account or Service (I) & Type of Account or Service (J) & Mean Difference (I-J) & Sig. \\
\hline \multirow{5}{*}{ Savings } & Current & -0.013 & 1.000 \\
\cline { 2 - 4 } & Fixed deposit & -0.413 & 0.036 \\
\cline { 2 - 4 } & Pawning & -0.224 & 0.075 \\
\cline { 2 - 4 } & Any other & 0.080 & 1.000 \\
\hline \multirow{5}{*}{ Current } & Savings & 0.013 & 1.000 \\
\cline { 2 - 4 } & Fixed deposit & -0.399 & 0.049 \\
\cline { 2 - 4 } & Pawning & -0.211 & 0.162 \\
\cline { 2 - 4 } & Any other & 0.093 & 1.000 \\
\hline \multirow{5}{*}{ Pixed deposit } & Savings & 0.413 & 0.036 \\
\cline { 2 - 4 } & Current & 0.399 & 0.049 \\
\cline { 2 - 4 } & Pawning & 0.188 & 0.780 \\
\cline { 2 - 4 } & Any other & 0.493 & 0.679 \\
\hline \multirow{5}{*}{ Any other } & Savings & 0.224 & 0.075 \\
\cline { 2 - 4 } & Current & 0.211 & 0.162 \\
\cline { 2 - 4 } & Fixed deposit & -0.188 & 0.780 \\
\cline { 2 - 4 } & Any other & 0.304 & 0.925 \\
\hline & Savings & -0.080 & 1.000 \\
\cline { 2 - 4 } & Current & -0.093 & 0.679 \\
\cline { 2 - 4 } & Fixed deposit & -0.493 & 0.925 \\
\cline { 2 - 4 } & Pawning & -0.304 & \\
\hline
\end{tabular}


As per the above table, it can be interpreted that there are significant differences in the service quality perceptions between and among the customers holding fixed deposit, savings and current accounts. As the $p$ values are less than the $5 \%$ level of significance $(\mathrm{p}=0.036 \& 0.049)$, this difference is significant.

\subsection{Combined Analysis of Service Quality}

Combined database (Employees' and customers' service quality variables) was analysed to check whether there are any differences in the study variable, service quality across demographic characteristics.

\subsubsection{Differences between employee perception and customer perception of service quality}

A database was created by linking employee and customer responses regarding service quality into a single database in order to carry out the analysis. Independent samples t-test was carried out to verify the difference and results are given in the following tables 9 and 10.

Table 9: Service quality (Group statistics - Respondent)

\begin{tabular}{|l|l|l|c|c|}
\hline Variable & Respondent & $\mathrm{N}$ & Mean & Standard deviation \\
\hline Service Quality & Employee & 225 & 4.0925 & 0.54451 \\
& Customer & 225 & 3.8807 & 0.48078 \\
\hline
\end{tabular}

Table 10: Service quality (Independent sample t-test analysis - Respondent)

\begin{tabular}{|l|c|c|c|c|c|}
\hline \multirow{2}{*}{ Variance Assumption } & \multicolumn{2}{|c|}{ Levene's test for equality of variance } & \multicolumn{3}{|c|}{ t-test for equality of means } \\
\cline { 2 - 6 } & $\mathrm{F}$ & $\mathrm{Sig}$ & $\mathrm{T}$ & $\mathrm{df}$ & $\mathrm{P}$-value \\
\hline Equal variance assumed & 6.661 & 0.010 & 4.374 & 448 & 0.000 \\
\hline Equal variance not assumed & & & 4.374 & 441.234 & 0.000 \\
\hline
\end{tabular}

Levene's test for equality of variances indicates that variances for respondents differ significantly ( $\mathrm{p}$ value, $0.010<0.05$ ) from each other. Then 'Equal-Variance Not Assumed' assumption was taken and t-test for equality of means was carried out to compare average values between respondents. As the p-value from the ttest for equality of means $(\mathrm{p}=0.000)$, is less than the significance level 0.05 , null hypothesis $\left(\mathrm{H}_{0}\right)$ was rejected and it was concluded that there is sufficient evidence to say, at the 5\% level of significance, that "there are significant differences between employees' perception and customers' perception of service quality of commercial banks in Batticaloa district". To support this finding, group statistics table can be utilized (refer Table 9). According to that table, mean value of employee service quality is 4.0925 , which is greater than the mean value of customer service quality, 3.8807. Employees perceive the quality of service provided by them in a higher level, but customers perceive the quality of the service they receive in a low level compared with employees.

\subsubsection{Differences between employees and customers}

It was concluded in section 6.6.1 that there are significant differences between employees' perception and customers' perception of service quality of commercial banks in Batticaloa district with 5\% level of significance. Here the analysis is performed again by splitting the variables based on nature of ownership (State and private banks) to explore whether these differences further differ between state and private banks. The results are presented in Table 11.

Table 11: Service quality (Independent sample t-test Analysis - Respondent \& Nature of ownership)

\begin{tabular}{|l|c|c|c|c|c|}
\hline \multirow{2}{*}{ Nature of Ownership } & \multicolumn{2}{|c|}{ Levene's test for equality of variance } & \multicolumn{3}{|c|}{ t-test for equality of means } \\
\cline { 2 - 5 } & $\mathrm{F}$ & $\mathrm{Sig}$ & $\mathrm{t}$ & $\mathrm{df}$ & $\mathrm{P}$-value \\
\hline Private Banks & 16.285 & 0.000 & 1.275 & 262.822 & 0.203 \\
\hline State Banks & 0.222 & 0.638 & 6.022 & 148 & 0.000 \\
\hline
\end{tabular}

'Equal variance not assumed' assumption was taken for private bank differences as the p-value for equality of variances $(\mathrm{p}=0.000)$ is less than 0.05 and 'Equal variance assumed' assumption was taken for state bank differences as the $p$-value for equality of variances $(p=0.638)$ is more than 0.05 . According to the results in the table 11 , there are differences in the perception of service quality only between the employees and customers of state banks $(\mathrm{p}=0.000<0.05)$. But, in case of private bank employees and customers, there are no differences in the service quality perceptions $(\mathrm{p}=0.203>0.05)$. To support this finding, group statistics table can be utilized (refer table 12). According to that table, mean value of employee service quality in state banks is 4.1051 , which is greater than the mean value of customer service quality in state banks, 3.5979. But no significant differences are found in the service quality mean values between the private bank employees and customers. Therefore, only in the state banks, the employees perceive the quality of service provided by them in a higher level, but customers perceive the quality of the service they receive in a low level compared with employees' perception. 
Table 12: Service quality (Group statistics - Respondent \& Nature of ownership)

\begin{tabular}{|l|l|l|c|c|}
\hline Nature of Ownership & Respondent & $\mathrm{N}$ & Mean & Standard deviation \\
\hline Private Banks & Employee & 147 & 4.0859 & 0.562 \\
& Customer & 153 & 4.0138 & 0.400 \\
\hline State Banks & Employee & 78 & 4.1051 & 0.533 \\
& Customer & 72 & 3.5979 & 0.518 \\
\hline
\end{tabular}

\subsubsection{Differences between private and state banks}

It was concluded in the section 6.6.2 that there are significant differences in service quality between state and private commercial banks in Batticaloa district at $5 \%$ level of significance. It was from the perception of customers. As the combined database has the service quality responses from both employees and customers, a further analysis is performed again by splitting the variables based on respondents (employees and customers) to explore whether these differences further differ between employees and customers of commercial banks. The results are presented in Table 13.

Table 13: Service Quality (Independent Sample t-test Analysis - Nature of Ownership \& Respondent)

\begin{tabular}{|l|c|c|c|c|c|}
\hline \multirow{2}{*}{ Respondents } & \multicolumn{2}{|c|}{ Levene's test for equality of variance } & \multicolumn{3}{|c|}{ t-test for equality of means } \\
\cline { 2 - 6 } & $\mathrm{F}$ & $\mathrm{Sig}$ & $\mathrm{t}$ & $\mathrm{df}$ & P-value \\
\hline Employees & 0.001 & 0.974 & -0.252 & 223 & 0.801 \\
\hline Customers & 8.904 & 0.003 & 6.025 & 112.342 & 0.000 \\
\hline
\end{tabular}

'Equal variance assumed' assumption was taken for employee differences as the $\mathrm{p}$ value for equality of variances $(\mathrm{p}=0.974)$ is more than 0.05 and 'Equal variance not assumed' assumption was taken for customer differences as the $p$ value for equality of variances $(p=0.003)$ is less than 0.05 . According to the results in the table 13, there are differences in the service quality between private and state banks only from the perception of customers $(\mathrm{p}=0.000<0.05)$. But there are no differences in the service quality between the private and state banks from the perceptions of employees $(\mathrm{p}=0.801>0.05)$. To support this finding, group statistics table can be utilized (refer table 14). According to that table, from the perception of customers, mean value of service quality in private banks is 4.0138 which is greater than the mean value of service quality in state banks, 3.5979. But no significant differences are found in the values between the private bank service quality and state bank service quality from the perception of employees. Therefore, the differences in service quality between the private and state banks are perceived only by customers not by employees.

Table 14: Service quality (Group statistics -Nature of ownership \& Respondent)

\begin{tabular}{|l|l|c|c|c|}
\hline Respondents & Nature of Ownership & $\mathrm{N}$ & Mean & Standard deviation \\
\hline Employees & Private Banks & 147 & 4.0859 & 0.562 \\
& State Banks & 78 & 4.1051 & 0.513 \\
\hline Customers & Private Banks & 153 & 4.0138 & 0.400 \\
& State Banks & 72 & 3.5979 & 0.518 \\
\hline
\end{tabular}

\section{Results and Discussion}

The objective of this study was to discover whether there are any differences between employees' and customers' perceptions towards service quality. Independent sample t-test was carried out to get the findings. It was concluded that there are significant differences between employees' perception and customers' perception of service quality of commercial banks in Batticaloa district. Employees perceived the quality of service they provide in a higher level while the customers perceived the quality of service they receive in a low level compared with employees' perception.

To get deeper knowledge on this finding, a comparison was made regarding this difference between private banks and state banks. It was found out that there are differences in the perception of service quality only between the employees and customers of state banks, not in private banks. The employees and customers of private banks perceived the service quality in the same level. A further analysis revealed that there are differences in the service quality between private and state banks only from the perception of customers. But there are no differences in the service quality between the private and state banks from the perceptions of employees. The customers of private banks perceive the service quality they receive in a high level compared with the customers of state banks. Because of that, there are differences in the perception of service quality between the employees and customers of state banks.

\section{Conclusion}

The research problem of this study is whether there are any differences between employees' perception and customers' perception of service quality. This problem has been addressed through the findings. It was pointed out that there are differences between employees' perception and customers' perception of service quality of the commercial banks in Batticaloa district (Manmunai North and Kattankudy DS divisions). In 
addition to that, significant differences in service quality were found out between state and private commercial banks in Batticaloa district. Service quality of private banks was perceived in a high level than the service quality in the state banks. In addition, differences exist in the service quality perceptions between and among the customers holding fixed deposit, savings and current accounts.

\section{References}

[1] Peng, L. Y. and Wang, Q. (2006). Impact of relationship marketing tactics (RMTs) on switchers and stayers in a competitive service industry, Journal of Marketing Management, 22(1,2), 25-59.

[2] Berry, L. C. and Parasuraman, A. (1997). Listening to the co-operative societies, the concept of a service quality information system, Sloan Management Review, Spring, pp. 61-76.

[3] Luk Serriff, T.K., and Roger Layton. (2002). Perception Gaps in Customer Expectations: Managers Versus Service Providers and Customers, The Service Industries Journal, 22(2), 109-128.

[4] Seiders, Kathleen. (2009). Understanding how employees understand customers: A commentary essay, Journal of Business Research, 62, 1136-1138.

[5] Rohini R., and B. Mahadevappa. (2006). Service Quality in Bangalore Hospitals - An Empirical Study, Journal of Services Research, 6, 1, 59-84.

[6] Pratyush, B. and Berg, D. (2003). Managing information systems for service quality: a study from the other side, Information Technology and People, Vol. 16 (2), pp. 182-202.

[7] Zeithaml, Parasuraman and Berry (1990). Delivering quality service; balancing customer perceptions and expectations, Free Press.

[8] Rust, R. T., and Oliver, R. L. (2005). Service quality: new direction in theory and practice, Thousand Oaks, CA: Sage, pp. 1-19.

[9] Gowan, M., Seymour, J., barreche, S., \& Lackey, C. (2001). Service quality in a public agency: same expectations but different perceptions by employees, managers, and customers, Journal of Quality Management, 6, 275-291. http://dx.doi.org/10.1016/S10848568(01)00040-2.

[10] Atkins, C. R., Dykes, P., Hagerty, J., \& Hoye, J. (2002). How customer performance partnerships can sharpen your competitive edge, The Journal for Quality and Participation, 25(3), pp 22-25.

[11] Bowden, P. (2000). Delivering organizational excellence by employee values management, Total Quality Management, 11, 636640. http://dx.doi.org/10.1080/09544120050007995.

[12] Vella, P.J., Gountas, J \& Walker, R. (2009). Employee perspectives of service quality in the supermarket sector, Journal of Services Marketing, 23(6), 407-421. http://dx.doi.org/10.1108/08876040910985870.

[13] Parasuraman, A., Zeithaml, V. A., and Berry, L. L. (1988). SERVQUAL: a multiple-item scale for measuring consumer perceptions of service quality, Journal of Retailing 64, pp.12-40.

[14] Vannirajan, T. and Manimaran, S. (2009). Management information systems for service quality in commercial banks: an empirical study, Asia Pacific Business Review 2009 5: 61, pp.61-75.

[15] Wikipedia. (n.d.). Quota sampling. Retrieved from http://en.wikipedia.org / wiki / Quota sampling

[16] Mesay Sata Shanka (2012). Bank service quality, customer satisfaction and loyalty in Ethiopian banking sector, Journal of Business Administration and Management Sciences Research Vol. 1(1), pp. 001-009.

[17] Baumann, C. (2007). Predication of attitude and behavioral intentions in retail banking, In T. J. Bank. Mark. 25(2): 102 - 11

[18] Hartline, Michael, D., Ferrell, O. C. (1996). The management of customer-contact service employees: an empirical investigation, J. Mark. 60 (11): 52-70.

[19] Babakus, E., and Boller, G. (1992). An empirical assessment of the SERVQUAL scale, Journal of Business Research (24)3, pp. 253-268.

[20] Wang (2003). The antecedents of service quality and product quality and their influences on bank reputation: evidence from banking industry in China, Managing Service Quality, 13: pp.72 - 83

[21] Lee, M. C., and Hwan, I. S. (2005). Relationships among service quality, customer satisfaction and profitability in the Taiwanese banking industry, Int. J. Manage. 22(4): pp.635-648.

[22] Zahoor (2011). SERPERF analysis in the banking services, Unpublished Master theses, Karachi Institute.

[23] Mensah (2010). Customer satisfaction in the banking industry: a comparative study of Spain and Ghana, Unpublished PhD Dissertation.

[24] Sulieman (2011). Banking service quality provided by commercial banks and customer satisfaction, American Journal of Scientific Research, ISSN 1450-223X Issue 27(2011), pp. 68-83.

[25] Coolican, H. (1999). Customer perceptions of service quality, Research Methods and Statistics in Psychology, 3rd edition, Great Britain: J. W. Ltd., Bristol, J. Retailing.

[26] Mouton, J., and Marais, H. C. (1990). Basic concepts in the methodology of the social Sciences, Human Sciences Research Council of Economics and Technology. 